This is the author's version of a work that was accepted for publication in Energy Economics.

Changes resulting from the publishing process, such as peer review, editing, corrections, structural formatting and other quality control mechanisms may not be reflected in this document. Changes may have been made to this work since it was submitted for publication. A definitive version was subsequently published in Energy Economics, Volume 44, July 2014, Pages 350-360.

http://doi.org/10.1016/j.eneco.2014.05.001 


\title{
RENEWABLE AND NON-RENEWABLE ENERGY CONSUMPTION AND ECONOMIC ACTIVITIES: FURTHER EVIDENCE FROM OECD COUNTRIES
}

\author{
Ruhul A. Salim* \\ School of Economics \& Finance, \\ Curtin Business School, \\ Curtin University, Perth, WA 6845 \\ Australia \\ Kamrul Hassan \\ School of Management and Governance, \\ Murdoch University, \\ 90 South St. Murdoch, WA 6150 \\ Australia \\ and \\ Sahar Shafiei \\ Department of Economics \\ Azad University, Science and Research Campus, \\ Ahvaz, Iran
}

*Corresponding author: Associate Professor Ruhul Salim, School of Economics \& Finance, Curtin Business School, Curtin University, Perth, WA 6102. Phone: +61 89266 4577, Fax: +61 892663026 ,

E-mail: Ruhul.Salim@cbs.curtin.edu.au 


\title{
RENEWABLE AND NON-RENEWABLE ENERGY CONSUMPTION AND ECONOMIC ACTIVITIES: FURTHER EVIDENCE FROM OECD COUNTRIES
}

\begin{abstract}
This article examines the dynamic relationship between renewable and non-renewable energy consumption and industrial output and GDP growth in OECD countries using data over the period of 1980-2011. The panel cointegration technique allowing structural breaks is used for empirical investigation. The results show that there is a long-term equilibrium relationship among non-renewable and renewable energy sources, industrial output and economic growth. The panel causality analyses show bidirectional causality between industrial output and both renewable and non-renewable energy consumption in the short and long run. However, there is evidence of bidirectional short-run relationship between GDP growth and non-renewable energy consumption while unidirectional causality between GDP growth and renewable energy consumption. These results indicate that OECD economies still remain energy-dependent for their industrial output as well as overall economic growth. However, expansion of renewable energy sources is a viable solution for addressing energy security and climate change issues, and gradually substituting renewable to non-renewable energy sources could enhance a sustainable energy economy.
\end{abstract}

Keywords: Cobb-Douglas production function; Renewable energy consumption; Nonrenewable energy consumption; Real GDP; Industrial output.

JEL classification: C23, C33, Q21, Q43, Q48

*Acknowledgement: Helpful comments from two anonymous referees and the editor of the journal, Richard Tol, are gratefully acknowledged, but the authors are responsible for any remaining errors or omissions. 


\section{RENEWABLE AND NON-RENEWABLE ENERGY CONSUMPTION AND ECONOMIC ACTIVITIES: FURTHER EVIDENCE FROM OECD COUNTRIES}

\section{Introduction}

Energy is a fundamental driver of output growth in OECD (Organization of Economic Cooperation and Development) countries. The average output growth remains at approximately $1.2 \%$ per annum, whereas energy consumption jumped from 197 quadrillion Btu in 1990 to 254 quadrillion Btu in 2010 (EIA, 2013) in these economies. The vast majority of this energy is generated from conventional sources, especially oil, coal, and gas. However, given concerns about climate change and global warming and political and social pressure to curb carbon dioxide gas emissions, OECD economies have demonstrated growing interest in renewable energy sources to both secure the energy supply and diversify the energy mix. This interest has been supported by various government policies, such as tax benefits, rebates, feed-in tariffs, and markets for renewable energy. As a result, the total investment in renewable energy has amounted to more than 1 trillion US dollars in OECD economies since 2002 , and renewable energy represents approximately $20 \%$ of the total energy supply in these economies (IEA, 2012).

In any economy, both renewable and nonrenewable energy use are strongly connected to the level of economic activity and economic growth. However, among the various sectors of the economy, the industrial sector dominates economic activities in OECD economies, consuming the largest portion of energy and producing a significant amount of carbon dioxide emissions. A number of studies have investigated these relationships between energy consumption, pollutant emissions, and economic growth. However, their findings are rather diverse, and there is a lack of consensus among economists. Most previous studies are aggregated analyses in which total energy consumption, pollutant emissions, and economic growth are evaluated. Exceptions to this approach are the studies of Apergis and Payne (2011, 2012) and Tugcu et al. (2012), who provide disaggregated analyses and contribute substantially to the literature. However, no study thus far has investigated the link between renewable and nonrenewable energy consumption and industrial output. Given the dominance of the industrial sector in the economic activities of the OECD economies, it is important to identify the links between renewable and nonrenewable energy consumption that 
are responsible for the dynamic industrial output growth as well as the steady economic growth of these mature economies.

This paper aims to analyze the relationship between renewable and non-renewable energy consumption and GDP growth in 29 OECD countries over the period of 1990-2012. It also seeks to contribute to the literature on the dynamic nexus between renewable and nonrenewable energy consumption and industrial output of these matured economies. We use the Common Correlated Effects Mean Group (CCEMG) estimator, proposed by Pesaran (2006) to examine long run relationship between dependent and independent variables. Following Liao et al. (2010) and Arbex and Perobelli (2010) we utilize a production function framework accounting for renewable and non-renewable energy consumption in addition to usual inputs: capital and labour. We also test for structural breaks in the data and examine the possibility of cross-sectional dependence (CSD) by following Carrion-i-Silvestre et al. (2005) and Pesaran (2004) respectively. The empirical results show that both renewable and non-renewable energy positively impacts GDP and industrial output. We also find the possibility of substitution of renewable energy for non-renewable energy. Using the Pooled Mean Group (PMG) model of Pesaran et al (1999) after time demeaning of variables to control for CSD, we find evidence of a bidirectional short-run relationship between GDP growth and nonrenewable energy consumption while unidirectional causality between GDP growth and renewable energy consumption. The later finding is contradictory with those of Apergis and Payne (2011a) who find unidirectional causality from GDP to renewable energy use. We also find bidirectional causality between industrial output and renewable and non-renewable energy consumption.

The remainder of the paper is organized as follows. Section 2 presents a review of the existing literature. The methodology is described in Section 3, followed by the empirical results in Section 4. Lastly, conclusions and policy implications are provided in Section 5.

\section{Review of the Existing Literature}

An impressive body of literature developed on the causal link between energy consumption, economic growth, and pollutant emissions after the seminal work by Kraft and Kraft (1978). There is no theoretical guide from the neoclassical school on the direction of this relationship, and the findings from the empirical literature are mixed. Some studies find that energy consumption leads to economic growth (growth hypothesis). These studies include Chontanawat et al. (2008), Narayan and Smyth (2008), Apergis and Payne (2009), Bowden and Payne (2009), Apergis and Payne (2010), and Yildirim and Aslan (2012). In a very recent 
paper, Apergis and Tang (2013) investigate the validity of the energy-led growth hypothesis using a different model specification and different stages of economic development for 85 selected countries. Overall, these authors find a systematic pattern, although the causality results for different countries are mixed. In particular, their results provide support for the energy-led growth hypothesis comparing less-developed or low-income countries to developed countries.

Another group of empirical studies demonstrates a bidirectional causal relationship (feedback hypothesis) between these variables. These studies include Apergis and Payne (2010a), Belke et al. (2011), Eggoh et al. (2011), Fuinhas and Marques (2012), and Kaplan et al. (2011). These authors argue that energy consumption drives economic growth, and economic growth contributes to energy consumption and pollutant emissions. However, Lise and Montfort (2007) and Huang et al. (2008) find unidirectional causality from economic growth to energy consumption (conservation hypothesis), whereas Soytas et al. (2007) does not find any causality (neutrality hypothesis) between these variables.

Recently, a new line of standard research has focused on the link between renewable energy consumption and economic growth. For instance, Payne (2011) demonstrated the validity of the growth hypothesis; Apergis and Payne (2010c, 2011a), proved the validity of the feedback hypothesis; and Menegaki (2011) demonstrated the validity of the neutrality hypothesis. Furthermore, Chien and Hu (2007) and Fang (2011) showed that an increase in the consumption of renewable energy sources positively contributes to economic growth, whereas Sadorsky (2009a) verified that the larger an economy grows, the more renewable energy sources are consumed.

Most recently, another line of standard research has decomposed the effects of energy consumption into renewable and non-renewable energy based on economic growth. Very few studies have been conducted in this line of research, including Sari and Soytas (2004), Payne (2009), Sadorsky (2009b), Apergis et al. (2010), Apergis and Payne (2012), and Tugcu et al. (2012). Using time series data over the period of 1946-2006 from the US, Payne (2009) finds an absence of Granger causality between renewable and non-renewable energy consumption and real GDP and thus supports the neutrality hypothesis. However, analyzing the causal relationship between $\mathrm{CO}_{2}$ emissions, nuclear energy consumption, renewable energy consumption, and economic growth for a group of 19 developed and developing countries, Apergis et al. (2010) finds bidirectional causality between renewable energy consumption and economic growth, supporting the feedback hypothesis. Similar findings are obtained by Apergis and Payne (2010d) for a panel of 20 OECD countries and by Sadorsky (2009a) for a 
panel of 18 emerging countries, in line with the short- and long-run bidirectional causality found by Apergis and Payne (2012) for a panel of 80 countries. These findings of bidirectional causality between renewable and non-renewable energy consumption and economic growth lend support to the feedback hypothesis, implying that renewable and nonrenewable energy consumption and economic growth are interdependent.

The empirical literature on the relationship between energy consumption and economic growth is extensive, and the findings are diverse. However, surveying the existing studies on the energy consumption-economic growth nexus, Ozturk (2010) concludes, "There is no consensus, neither on the existence nor on the direction of causality between these variables in the literature" (P: 347). Therefore, the literature on this issue continues to grow. Few studies on OECD countries provide a disaggregated analysis of renewable and nonrenewable energy consumption and economic growth. Therefore, the present study aims to contribute to the literature by identifying the impacts of renewable and non-renewable sources of energy on the real gross domestic product and on the industrial sector in OECD countries.

\section{Methodology}

\subsection{Theoretical Framework}

Recent literature concerning economic growth indicates that capital, labor, technological progress, and energy are the basic elements of economic growth in developed countries. The analytical framework used here is developed by Liao et al (2010) and justified by Arbex and Perobelli (2010). Accordingly, this study augments the neoclassical Cobb-Douglas production function by incorporating renewable and non-renewable energy consumption in addition to capital and labor employment in estimating the long-run relationship between variables. Although the mainstream neoclassical growth models do not include energy as a factor in the production function that could constrain or enable economic growth the recent literature pay attention to this for substitution of other inputs for energy particularly renewable energy due to high oil price and the fear of so called 'peak oil'. Thus, optimum adjustment of fuel mix has never been more important than now and the economic outcome of decisions regarding energy policy often hinges on substitution between energy sources and other factors of production. Hence, accurately estimating and analyzing the linkages between renewable and non-renewable energy consumption and industrial output as well as GDP growth can provide some information for governments as a basis of setting up appropriate policies related to environment such as pollution and energy taxes. 
Let the production function be of the following form:

$$
Y_{t}=A K_{t}^{\alpha} L_{t}^{\beta} E_{t}^{\gamma}
$$

where $Y_{t}$ represents the aggregate output at time $t, K_{t}$ is capital, $L_{t}$ is labor, $E_{t}$ is energy, and $A$ is the technology parameter. $A, \beta$, and $\gamma$ measure the elasticities of output with respect to capital, labor, and energy, respectively. According to Liao et al. (2010) and Arbex and Perobelli (2010), energy is classified into two categories, clean energy (renewable) and nonclean energy (non-renewable). The production procedure uses both resources as sources of energy. Consequently, the above function is adjusted as follows:

$$
Y_{t}=A K_{t}^{\alpha} L_{t}^{\beta} R_{t}^{\gamma_{1}} N_{t}^{\gamma_{2}}
$$

where $R_{t}$ is renewable energy and $N_{t}$ is non-renewable energy. Here, $\gamma_{1}$ and $\gamma_{2}$ are the elasticity of output with respect to renewable and non-renewable energy, respectively. The logarithmic form of the production function provides a log-linear form and yields

$$
\operatorname{Ln} Y_{t}=\operatorname{Ln} A+\alpha \operatorname{LnK} K_{t}+\beta \operatorname{Ln} L_{t}+\gamma_{1} \operatorname{LnR}+\gamma_{2} \operatorname{LnN} N_{t}+u_{t} .
$$

In the above model, $Y$, as the dependent variable, represents real gross domestic production, and $K, L, R$, and $N$, as independent variables, stand for capital, labor, renewable energy consumption, and non-renewable energy consumption, respectively. The economic explanations of $\alpha, \beta, \gamma_{1}$, and $\gamma_{2}$ are the elasticities of output with respect to capital, labor, renewable energy, and non-renewable energy, respectively.

To identify the linkages between various types of energy and industrial production, Equation (3) is also estimated using industrial output as the dependent variable as follows:

$$
L n I V_{t}=\operatorname{LnA}+\alpha \operatorname{LnK_{t}}+\beta \operatorname{Ln} L_{t}+\gamma_{1} \operatorname{LnR} R_{t}+\gamma_{2} \operatorname{LnN} N_{t}+u_{t}
$$

where $\operatorname{LnIV}_{t}$ is industrial value added. In empirical analysis that follows equation (3a) and (3b) are referred to as Model I and Model II respectively.

\subsection{Econometric Approach}

3.2.1. Unit root: In the empirical analysis, the time series properties of variables must be examined to avoid the possibility of spurious regression. In the first step, the integrational properties of the series are ascertained. To achieve this goal and to provide an analysis of sensitivity and robustness, this study performs three different unit root tests, including Breitung (2000), Levin et al. (2002) (LLC), and Im et al. (2003) (IPS). Breitung (2000) proposes a $t$-ratio type test statistic that does not require bias correction factors. It is also a test against the homogenous alternative due to its pooled construction. The LLC is based on the augmented Dickey-Fuller (ADF) test and assumes homogeneity in the dynamic of the 
autoregressive (AR) coefficients for all panel members. Specifically, the LLC test assumes that each individual unit in the panel shares the same $\operatorname{AR}(1)$ coefficient but allows for an individual effect, time effects, and, eventually, a time trend. The IPS suggests a new, more flexible, and computationally simple unit root testing procedure for panels that allows for simultaneous stationary and non-stationary series. Moreover, this test allows for residual serial correlation and heterogeneity of the dynamics and error variances across groups. All tests discussed here rely on the assumption of cross-sectional independence and treat the presence of a unit root, implying non-stationarity as the null hypothesis, and the absence of the unit root, or stationarity as the alternative hypothesis.

3.2.2: Panel cointegration: According to Perron (1989), although different tests are widely used to check for stationarity, failure to allow for structural breaks can lead to deceptive results. To overcome this problem, a panel stationarity test allowing for multiple structural breaks by following Carrion-i-Silvestre et al. (2005) is applied in this study. The procedure for this test is based on the panel data version of the Kwiatkowski (1992) univariate test developed in Hadri (2000). Some of the features of this test are that, first, it allows for the structural changes to shift the mean and/or the trend of the individual time series. Second, each individual in the panel can have a different number of breaks located at different dates.

In the second step, panel cointegration relationships between the variables are tested by using the recently introduced test by Westerlund (2007). This test has high power relative to commonly used residual-based panel cointegration tests such as Pedroni (2004). Moreover, the results of the Westerlund test are sensitive to the choice of lag and lead lengths when the time dimension is short (Persyn and Westerlund 2008). A drawback of Pedroni's test is that it does not accommodate structural breaks. Westerlund test allows for multiple structural breaks in the data and determines the location of structural breaks endogenously using the Bai and Perron (2003) technique, which globally minimizes the sum of squared residuals.

The panel cointegration test is conducted under two different models:

Model I: Output $(\mathrm{GDP})=f($ gross fixed capital formation $(\mathrm{K})$, total labor force $(\mathrm{L})$, renewable energy consumption $(\mathrm{R})$, non-renewable energy consumption $(\mathrm{N})$ ).

Model II: Industrial output (IV) $=f($ gross fixed capital formation $(\mathrm{K})$, total labor force $(\mathrm{L})$, renewable energy consumption $(\mathrm{R})$, non-renewable energy consumption $(\mathrm{N})$.

3.2.3: Long-run estimators: Diagnostic tests reported in Table 1 indicate that Model I suffers from the problem of cross-section dependence, heteroskedasticity and serial correlation and Model II suffers from heteroskedasticity and serial correlation. When models suffer from 
these problems conventional panel estimators (such as fixed or random effects) can result in misleading inference and even inconsistent estimators (Phillips and Sul, 2007). Pesaran (2006) proposes an estimation method, called Common Correlated Effects (CCE), which allows for unobserved factors to be correlated with exogenous regressors and idiosyncratic components to be independent across countries. Furthermore, this estimator holds under different situations such as serial correlation in errors, unit roots in the variables and possible contemporaneous dependence of the observed regressors with the unobserved factors (Kapetanios and Pesaran, 2007; Pesaran and Tosetti, 2011). In this step we employ Common Correlated Effects Mean Group (CCEMG) estimator, proposed by Pesaran (2006), to estimate the long-run estimators that account for cross-sectional dependence. The idea of this estimator is to filter the cross-section specific regressors by cross-section averages of dependent variable and the observed regressors. In this way cross-section dependence can be eliminated as unobserved common factor can well be approximated by the cross-section averages. Kapetanios et at (2011) note that CCEMG estimators are consistent even in the presence of unit root in the unobserved factors. CCEMG estimator is also robust to local and global shocks (Pesaran and Tosetti, 2011).

3.2.4: Granger causality: To identify the short-run and long-run causality among the variables we employ dynamic panel data framework proposed by Pesaran et al (1999), commonly known as Pooled Mean Group (PMG) estimation. PMG estimators allow intercept, slope coefficients and error variance to vary across cross-section members and thus recognize heterogeneity among cross-section units of the panel. PMG estimator is superior to its predecessor Mean Group (MG) estimator of Pesaran and Smith (1995). Under slope coefficients' heterogeneity the MG estimator does not take into account that some economic conditions tend to be same across cross-section units in the long run. The efficiency gain of PMG estimator comes from the assumption of heterogeneous short-run dynamics and the constraint that the long-run coefficient to be equal across cross-section units. There are other obvious advantages of PMG estimator. It is robust to outliers and the choice of lag orders (Pesaran et al, 1999). It is consistent and efficient even in the presence of endogenous and non-stationary regressors (Fayad, 2010). Other candidate methodology to estimate dynamic panel models are fixed effects, instrumental variables or Generalized Methods of Moments (GMM) estimators. However, Pesaran and Smith (1995) show that for panels with larger time dimension (T) these estimators can produce inconsistent and very misleading estimates of the parameters. GMM is suitable short panels where $\mathrm{N}>\mathrm{T}$. In the present paper we have 29 cross- 
section units $(\mathrm{N}=29)$ and 32 yearly observations $(\mathrm{T}=32)$, that is $\mathrm{N}<\mathrm{T}$, therefore we choose to employ PMG estimator to analyze short-run and long-run causality among the variables. The PMG approach is modelled as an autoregressive distributed lag (ARDL) model. Let the $\operatorname{ARDL}\left(p, q_{1}, q_{2}, \ldots . q_{k}\right)$ dynamic panel model is specified as follows:

$$
y_{i t}=\sum_{1}^{p} \lambda_{i j} y_{i, t-j}+\sum_{j=0}^{q} \delta_{i j}^{\prime \prime} \mathrm{X}_{i, t-j}+\mu_{i}+\varepsilon_{i t}
$$

Where the number of cross-section units $I=1,2, \ldots . \mathrm{N}$; from 1 to $\mathrm{N}$; the number of period $t=$ $1,2, \ldots . T . \mathbf{X}_{\mathrm{it}}$ is a $k \times 1$ vector of explanatory variables; $\delta_{i t}$ is the $k \times 1$ coefficient vector; $\lambda_{i j}$ are scalars and $\mu_{i}$ is the cross-section specific effect. For convenience Equation [4] can be reparameterized as follows:

$$
\begin{aligned}
& \Delta y_{i t}=\phi_{i}\left(y_{i, t-1}-\theta_{i}^{\prime} \mathrm{X}_{i t}\right)+\sum_{j=1}^{p-1} \lambda_{i j}^{*} \Delta y_{i, t-1}+\sum_{j=0}^{q-1} \delta_{i j}^{\prime^{*}} \Delta \mathrm{X}_{i, t-j}+\mu_{i}+\varepsilon_{i t} \\
& \text { Where, } \quad \phi_{i}=-\left(1-\sum_{j=1}^{p} \lambda_{i j}\right), \theta_{i}=\frac{\sum_{j=0}^{q} \delta_{i j}}{\left(1-\sum_{k} \lambda_{i k}\right)} ; \lambda_{i j}^{*}=-\sum_{m=j+1}^{p} \lambda_{i, m}, j=1,2, . ., p-1, \text { and } \\
& \delta_{i j}^{\prime *}=-\sum_{m=j+1}^{q} \delta_{i, m}, j=1,2, . ., q-1 .
\end{aligned}
$$

The parameter $\phi_{i}$ is the error-correction speed of adjustment term. If the null of $\phi=0$ is rejected then there would be evidence of long-run equilibrium relationship, that is, the variables are cointegrated. In this case the parameter value is expected to be significantly negative. Significant value of this error-correction term can also be taken as the evidence of long-run causality running from independent to dependent variable. For short run causality from independent to dependent variable we need the null hypothesis of $\delta_{i j}^{\prime *}=0$ in Equation (5) to be rejected (Santana-Gallego et al., 2011). For our purpose we can specify Equation (5) in terms of variables in Equation [3a and 3b]. For example, in Equation (3a) $\operatorname{Ln} Y$ is the dependent variable and $L n A, L n K, L n L, L n R$ and $L n N$ are independent variables. Now we want to examine causal link running from independent to dependent variables, we can rewrite Equation (5) in terms of $\operatorname{LnY}$ as follows:

$$
\Delta L n Y_{i t}=\phi_{i}\left(\operatorname{Ln} Y_{i, t-1}-\theta_{i}^{\prime} \mathrm{X}_{i t}\right)+\sum_{j=1}^{p-1} \lambda_{i j}^{*} \Delta \operatorname{Ln} Y_{i, t-1}+\sum_{j=0}^{q-1} \delta_{i j}^{* *} \Delta \mathrm{X}_{i, t-j}+\mu_{i}+\varepsilon_{i t}
$$

Where $\mathrm{X}$ is the vector of $\operatorname{LnA}, \operatorname{LnK}, \operatorname{LnL}, \operatorname{LnR}$ and $L n N$. Similarly if we want to examine causal link running from $\operatorname{LnA}, \operatorname{LnK}, \operatorname{Ln} L, \operatorname{LnR}$ and $\operatorname{Ln} Y$ to $\operatorname{LnN}$, then the resulting equation will be: 


$$
\Delta L n N_{i t}=\phi_{i}\left(L n N_{i, t-1}-\theta_{i}^{\prime} \mathrm{X}_{i t}\right)+\sum_{j=1}^{p-1} \lambda_{i j}^{*} \Delta L n Y_{i, t-1}+\sum_{j=0}^{q-1} \delta_{i j}^{\prime *} \Delta \mathrm{X}_{i, t-j}+\mu_{i}+\varepsilon_{i t}
$$

In this way we can specify equations for other variables and examine short and long run causality among the variables.

\subsection{Data Description}

Annual data for a set of 29 OECD countries covering the period from 1980 to 2012 are collected on gross domestic product, industrial output, capital, labor force, and renewable and non-renewable energy consumption for a balanced panel with 928 observations for the selected OECD countries. The 29 sample countries are Australia, Austria, Belgium, Canada, Chile, Denmark, Finland, France, Germany, Greece, Hungary, Iceland, Ireland, Italy, Japan, South Korea, Luxembourg, Mexico, the Netherlands, New Zealand, Norway, Poland, Portugal, Spain, Sweden, Switzerland, Turkey, the United Kingdom, and the United States. Due to the unavailability of data, only 29 of the 34 countries that constitute the OECD are included in the analysis.

In this study, real GDP in billions of constant 2000 U.S. dollars using purchasing power parities (PPPs) is used as a proxy for economic output. Capital, which is used as an input in the production function, refers to already-produced durable goods. Because capital stock data are not easy to collect and measure, gross fixed capital formation is usually used as a proxy for the growth of capital stock. Particularly, in accordance with the perpetual inventory method, assuming a constant depreciation rate indicates that changes in investment closely follow changes in the capital stock (Soytas and Sari 2006). Thus, data on real gross fixed capital formation in billions of constant 2000 U.S. dollars are used in this study. Data on the total labor force in millions as well as industrial value added (as a proxy for industrial output) in billions of constant 2000 U.S. dollars are also applied. All data mentioned above are obtained from the World Bank (2013).

According to the Energy Information Administration (2011), non-renewable energy sources include coal and coal products, oil, and natural gas. Therefore, in this study, nonrenewable energy consumption is measured as the aggregate of the consumption of all of these sources in quadrillion Btu units. Renewable energy consumption in quadrillion Btu units is measured as wood, waste, geothermal, wind, photovoltaic, and solar thermal energy consumption. All data related to energy consumption are sourced from the U.S. Energy Information Administration. 
All variables are converted into natural logarithms prior to conducting the analysis so that the parameter estimates of the model can be interpreted as elasticity estimates. To test for multi-collinearity between the independent variables in each model, the variance inflation factors (VIF) for each predictor are calculated (not shown here to save space). The results indicate no existence of mult-icollinearity between the independent variables in each of the models.

\section{Empirical Results}

With panel data, the most commonly estimated models are fixed effects and random effects models. Fixed effects models control for the effects of time-invariant variables with timeinvariant effects. In the fixed effects model, the individual-specific effect is a random variable that is allowed to be correlated with the explanatory variables. In the random effects model, the individual-specific effect is a random variable that is uncorrelated with the explanatory variables. It should be noted that using these methods without controlling for diagnostic tests such as cross-sectional dependence, heteroskedasticity, and serial correlation can cause bias in the standard errors and produce inefficient results. Pesaran indicates that the cross-sectional dependence (CD) test allows for a wide variety of models, including heterogeneous dynamic models with multiple breaks and non-stationary dynamic models with a small or large time-series dimension $(T)$ and cross-sectional dimension $(N)$. In the present study, Pesaran's (2004) CD test is applied to check for cross-section dependence.

Table 1: Diagnostic tests for Models I and II

\begin{tabular}{lll}
\hline & FE Estimation & RE Estimation \\
\hline $\begin{array}{l}\text { Model I } \\
\begin{array}{l}\text { Pross-Sectional Dependence } \\
\text { Heteroskedasticity }\end{array}\end{array}$ & $0.000^{* * *}$ & \\
$\begin{array}{l}\text { Modified Wald }(P \text {-value }) \\
\text { Serial Correlation } \\
\text { Wooldridge }(P \text {-value })\end{array}$ & $0.000^{* * *}$ & $0.000^{* * *}$ \\
$\begin{array}{l}\text { Model II } \\
\begin{array}{l}\text { Cross-Sectional Dependence } \\
\text { Pesaran }(P \text {-value })\end{array}\end{array}$ & $0.000^{* * *}$ & \\
$\begin{array}{l}\text { Heteroskedasticity } \\
\text { Modified Wald }(P \text {-value }) \\
\text { Serial Correlation } \\
\text { Wooldridge }(P \text {-value })\end{array}$ & 0.2470 & \\
\hline
\end{tabular}

Note: FE and RE denote fixed effects and random effects estimations. *** and * indicate that the $P$ value or test statistic is significant at the $1 \%$ and $10 \%$ levels, respectively. 
The problem of heteroskedasticity in cross-section data occurs when the variance of the unobservable error (disturbance) is not constant. Although heteroskedasticity does not affect the parameter estimates, it does bias the variance of the estimated parameters. The frequently used tests for heteroskedasticity are the Breusch-Pagan test, or the Lagrange Multiplier test, the likelihood ratio test, and the standard Wald test. The weakness of these tests is their sensitivity to the normality assumption. Therefore, in this study, a modified Wald test is used to check for the presence of panel heteroskedasticity because this test works even when the normality assumption is violated.

Autocorrelation is occasionally called "lagged correlation" or "serial correlation", which refers to the correlation between members of a series of numbers arranged in time. Positive autocorrelation can be considered a specific form of "persistence", a tendency for a system to remain in the same state from one observation to the next. Wooldridge (2002) derives a flexible test for detecting serial correlation in panel data models.

Table 2: Panel unit root test without structural breaks for the variables used in Models I and II

\begin{tabular}{lllllll}
\hline Method & LnY & LnIV & LnK & LnL & LnR & LnN \\
\hline Breitung & & & & & & \\
Level & 4.336 & 1.848 & 0.183 & 1.071 & 6.170 & -1.093 \\
& $(1.000)$ & $(0.967)$ & $(0.572)$ & $(0.858)$ & $(1.000)$ & $(0.137)$ \\
First & -2.929 & -4.525 & -4.563 & -6.262 & -10.406 & -8.048 \\
difference & $(0.001)^{* * *}$ & $(0.000)^{* * *}$ & $(0.000)^{* * *}$ & $(0.000)^{* * *}$ & $(0.000)^{* * *}$ & $(0.000)^{* * *}$ \\
LLC & & & & & & \\
Level & 13.007 & -0.523 & 7.691 & 1.162 & 2.525 & -0.971 \\
& $(1.000)$ & $(0.300)$ & $(1.000)$ & $(0.877)$ & $(0.994)$ & $(0.165)$ \\
First & -5.711 & -8.444 & -3.274 & -3.791 & -22.953 & -18.642 \\
difference & $(0.000)^{* * *}$ & $(0.000)^{* * *}$ & $(0.000)^{* * *}$ & $(0.000)^{* * *}$ & $(0.000)^{* * *}$ & $(0.000)^{* * *}$ \\
IPS & & & & & & \\
Level & 5.128 & 2.756 & 3.573 & 3.525 & 3.187 & 1.288 \\
& $(1.000)$ & $(0.997)$ & $(0.999)$ & $(0.999)$ & $(0.999)$ & $(0.901)$ \\
$\begin{array}{l}\text { First } \\
\text { difference }\end{array}$ & -7.832 & -11.469 & -7.119 & -5.780 & -26.069 & -21.815 \\
\hline Net & $(0.000)^{* * *}$ & $(0.000)^{* * *}$ & $(0.000)^{* * *}$ & $(0.000)^{* * *}$ & $(0.000)^{* * *}$ & $(0.000)^{* * *}$ \\
\hline
\end{tabular}

Note: Probabilities of the test statistics are presented in parentheses. ***,**, and * indicate that the test statistic is significant at 1\%,5\%, and 10\% level, respectively. The Schwarz Information Criterion (SIC) is used to determine the optimal lag length. The nulls for all tests are unit roots, and all regressions include an intercept and trend.

The results of the diagnostic tests are provided at this stage to select an appropriate method for estimating the long-run relationship between the variables in the two models. The results of the diagnostic tests for the two models are provided in Table 1. Pesaran's test rejects the null hypothesis of cross-sectional independence for Model I under both fixed and random effect specifications. However, for Model II the null of cross-sectional independence under both fixed and random effect specification are not rejected. The results of heteroskedasticity 
and serial correlation tests confirm the existence of the problem of heteroskedasticity and serial correlation at a $1 \%$ level of significance in the models.

\subsection{Panel Unit Root Test}

The results of the unit root tests, including Breitung (2000), Levin et al. (2002) (LLC), and Im et al. (2003) (IPS), are presented in Table 2. All of these tests treat the presence of a unit root, implying non-stationarity as the null hypothesis, and the absence of the unit root or stationarity as the alternative hypothesis. Individual trends and constants are included in the tests. The statistics significantly confirm that the level values of all series are non-stationary, and the first differences of all variables in all tests are stationary at the $1 \%$ level of significance.

Table 3: Panel unit root test with structural breaks for the variables used in Models I and II

\begin{tabular}{llllll}
\hline Variables & Bartlett & Quadratic & \multicolumn{3}{c}{ Critical values } \\
\cline { 5 - 6 } & Kernel & Kernel & $5 \%$ & $2.5 \%$ & $1 \%$ \\
\hline LnY & & & & & \\
Homogeneous & $11.127^{*}$ & $11.265^{*}$ & 11.012 & 11.893 & 12.075 \\
Heterogeneous & $11.090^{* *}$ & $11.304^{* *}$ & 10.208 & 10.919 & 11.871 \\
LnIV & & & & & \\
Homogeneous & $18.384^{* *}$ & $19.561^{* * *}$ & 17.091 & 17.628 & 18.631 \\
Heterogeneous & $20.004^{* *}$ & $21.431^{* * *}$ & 18.562 & 19.853 & 20.673 \\
LnL & & & & & \\
Homogeneous & $9.139^{* * *}$ & $9.140^{* * *}$ & 5.509 & 5.854 & 6.006 \\
Heterogeneous & $11.973^{* * *}$ & $12.002^{* * *}$ & 6.704 & 7.310 & 7.656 \\
LnK & & & & & \\
Homogeneous & $7.841^{* * *}$ & $7.843^{* * *}$ & 7.092 & 7.806 & 8.666 \\
Heterogeneous & $8.722^{* *}$ & $8.734^{* *}$ & 6.695 & 7.723 & 8.991 \\
LnR & & & & & \\
Homogeneous & $7.734^{* *}$ & $7.611^{* *}$ & 6.821 & 7.010 & 7.812 \\
Heterogeneous & $6.913^{* * *}$ & $6.742^{* * *}$ & 5.431 & 5.912 & 6.729 \\
LnN & & & & & \\
Homogeneous & $8.893^{* *}$ & $8.897^{* *}$ & 8.711 & 8.991 & 9.123 \\
Heterogeneous & $9.710^{* *}$ & $9.783^{* *}$ & 9.512 & 9.703 & 10.111 \\
\hline
\end{tabular}

Note: The number of structural breaks is up to five. The long-run variance is estimated using both the Bartlett and the quadratic spectral kernel with automatic spectral window bandwidth selection, as in Sul et al. (2005). ***,**, and * indicate that the test statistic is significant at the $1 \%, 2.5 \%$, and $5 \%$ levels, respectively.

Table 3 provides the results of the panel stationarity test with structural breaks by following Carrion-i-Silvestre et al. (2005). These results indicate that the null hypothesis of stationarity is rejected by either the homogeneous and heterogeneous long-run variance for all variables at the $5 \%$ level and for most of the variables at the $2.5 \%$ and $1 \%$ levels. Thus, it can be concluded that all the variables are non-stationary at their levels even when allowing 
structural breaks. The country-by-country tests with multiple breaks allowing for a maximum of five breaks are calculated by means of Monte Carlo simulations based on 20,000 replications. The results are provided in Appendix Table 1. There is more than one break in different series in all 29 countries. These breaks are typically coincident with various episodic events as well as domestic economic and financial deregulations in individual country. For example, oil price shocks in the early 1980s, Asian financial crisis in 1998-99, slowdown of various big economies such as the US in 2001, US stock market collapse, terrorist attacks in New York, Afghanistan and Iraq wars in the 2000s and some big businesses collapsed in the mid-2000s and so on. All these events contributed to the structural breaks in various series.

Overall, the results of the panel unit root tests for all variables used in this study confirm that the level values of all series are non-stationary, and all variables are stationary at the first difference; that is, all variables are integrated at order one. Consequently, panel cointegration tests can be employed to study the long-run equilibrium process.

\subsection{Panel Cointegration Test}

Following Westerlund (2006 and 2007), the cointegration results for Models I and II are reported in Tables 4 and 5. The results of Westerlund's (2007) cointegration test without structural breaks (Table 4) for Model I shows that group- $\alpha$ and panel- $\alpha$ test statistics are insignificant, while group- $\tau$ and panel- $\tau$ test statics are significant indicating some signs of cointegration. We suspect that this result may be due to existence of cross-sectional dependence. To accommodate cross-sectional dependence we apply bootstrap technique and the resulting $p$-values are reported under 'Bootstrapped $p$ value' column in Table 5. These $p$ values indicate that when cross-sectional dependence is taken into consideration, the variables in Model I are found cointegrated. However, the results for Model II, even with bootstrapped $p$-values, indicate that the variables are not cointegrated. Table 5 presents the panel cointegration test results with structural breaks. For Model I, the statistic Z(m) cannot reject the null hypothesis of cointegration at the $5 \%$ and $1 \%$ significance levels, and the DOLS-based (Dynamic Ordinary Least Squares) statistics cannot reject the null hypothesis, even at the $10 \%$ significance level. The same results are observed for Model II. These results provide some evidence of cointegration in the presence of structural breaks, implying that, when structural break is considered, evidence of a long-run equilibrium relationship is found between GDP, capital, labor force, and renewable and non-renewable energy consumption in selected OECD countries. 
Table 4: Westerlund cointegration test without structural breaks for Models I and II

\begin{tabular}{llcl}
\hline Statistic & Value & $P$-value & Bootstrapped \\
\hline & & Model I & \\
\hline Group- $\tau$ & -3.250 & $0.014^{* *}$ & $0.034^{* *}$ \\
Group- $\alpha$ & -7.835 & 1.000 & $0.064^{*}$ \\
Panel- $\tau$ & -15.226 & $0.058^{*}$ & $0.030^{* *}$ \\
Panel- $\alpha$ & -7.521 & 1.000 & $0.068^{*}$ \\
\hline & & Model II & \\
\hline Group-t & -2.467 & 0.989 & 0.520 \\
Group-a & -5.950 & 1.000 & 0.634 \\
Panel-t & -10.363 & 1.000 & 0.606 \\
Panel-a & -5.888 & 1.000 & 0.496 \\
\hline
\end{tabular}

Note: $* * *, * *$ and $*$ indicate that the test statistics are significant at $-1 \%, 5 \%$ and $10 \%$ levels respectively. Following Westerlund (2007), the maximum lag length is selected according to $4(T / 100)^{2 / 9}$. The null hypothesis of the test is "no cointegration".

Table 5: Westerlund cointegration test with structural breaks for Models I and II

\begin{tabular}{lllll}
\hline & Statistics & \multicolumn{3}{c}{ Critical Values } \\
\cline { 3 - 5 } & & \multicolumn{2}{c}{ Model I } & $1 \%$ \\
\hline $\mathrm{Z}(\mathrm{m})$ & 7.312 & 7.045 & 9.211 & 13.117 \\
$\mathrm{Z}_{\text {DOLS }}(\mathrm{m})$ & 7.731 & 10.102 & 12.429 & 16.658 \\
\hline \multicolumn{5}{c}{ Model II } \\
\hline $\mathrm{Z}(\mathrm{m})$ & 8.111 & 7.843 & 11.531 & 13.348 \\
$\mathrm{Z}_{\text {DOLS }}(\mathrm{m})$ & 9.014 & 9.332 & 11.210 & 14.537 \\
\hline
\end{tabular}

The null hypothesis of the test is "cointegration".

\subsection{Long-Run Estimation}

Pesaran's (2006) long-run CCEMG estimates are reported in Table 6. The estimates are free from cross-sectional dependence and time-variant heterogeneity. We present results for both models. The results show that in both models all variables are highly significant except the coefficient of (log of) labor. The results for Model I show that in the long run, a $1 \%$ increase in capital, total labor force, renewable energy and non-renewable energy consumption will enhance real GDP by $0.254 \%, 0.817 \%, 0.101 \%$, and $0.267 \%$, respectively. Comparing the coefficients of the independent variables indicates that labor has the largest effect on real GDP in the long run. In addition, the elasticities of real GDP with respect to renewable and non-renewable energy consumption demonstrate that both types of energy stimulate economic growth in OECD countries. However, comparing the magnitudes of their coefficients confirms that non-renewable energy is still the dominant type of energy utilized in the process of economic growth. A comparison with other studies in which the effects of renewable and non-renewable energy consumption on economic growth are simultaneously 
investigated show that the results obtained here are consistent with those reported by Apergis and Payne (2013) for 85 developed and developing countries. However, the results differ from those obtained by Apergis and Payne (2011a) and Apergis and Payne (2012), who find a positive and significant impact only for non-renewable energy consumption in six Central American countries and in 16 emerging countries, respectively. The positive and significant relationship between renewable energy consumption and economic growth in the long term is also found by Apergis and Payne (2010d) for 20 OECD countries, Apergis and Payne (2010c) for 13 Eurasian countries, and Apergis and Payne (2011a) for six Central American countries.

Table 6: CCEMG estimates of Model I and Model II

\begin{tabular}{lll}
\hline Independent variables & Model I & Model II \\
\hline \multirow{2}{*}{$\ln K$} & $0.2545^{* * *}$ & $0.4346^{* * *}$ \\
& $(0.0360)$ & $(0.0457)$ \\
$\operatorname{Ln} L$ & $0.8175^{* * *}$ & 0.1234 \\
& $(0.1986)$ & $(0.3109)$ \\
$\operatorname{Ln} R$ & $0.1018^{* * *}$ & $0.0745^{* * *}$ \\
& $(0.0190)$ & $(0.0253)$ \\
$\operatorname{Ln} N$ & $0.2670^{* * *}$ & $0.2955^{* * *}$ \\
\multirow{2}{*}{ Intercept } & $(0.0534$ & $(0.0788)$ \\
& -2.3919 & -0.2221 \\
& $(1.4930)$ & $(2.3495)$ \\
\hline
\end{tabular}

***, ** and * indicate that the test statistics are significant at $1 \%, 5 \%$ and $10 \%$ levels respectively. Figures in the parentheses are standard errors.

Although Model II does not suffer from the cross-sectional dependence, it is not free from the problems of heteroskedasticity and serial correlation. We, therefore, also present estimations results of Model II. The coefficients of capital, renewable and non-renewable energy consumption are positive and statistically significant at the $1 \%$ level. However, the coefficient of labor force consumption is positive, but not statistically significant. This may reflect the fact that industrial sectors in OECD countries are highly automated and less labor intensive and hence insignificant coefficient for labor force variable. The findings show that a $1 \%$ increase in capital, renewable and non-renewable energy consumption enhances industrial output by $0.434 \%, 0.074 \%$, and $0.295 \%$, respectively. Comparing the results of Model I and II with regard to energy consumption we see that in both cases the elasticity of non-renewable energy consumption is greater than the elasticity of renewable energy consumption and the elasticity figures are quite close to each other (0.267 vs 0.295$)$. 


\subsection{Panel Granger Causality}

We employ Pooled Mean Group (PMG) estimator proposed by Pesaran et al (1999) to capture causal link among the variables in Model I. PMG estimator does not handle the problem of cross-sectional dependence. According to the diagnostic tests results in Table 1, Model I suffers from cross-sectional dependence problem. To eliminate the problem of crossscetional dependence we transform the variables by time demeaning the data in which case a panel model takes the following form:

$$
\begin{aligned}
& \left(y_{i t}-\bar{y}_{. t}\right)=\left(\alpha_{i}-\bar{\alpha}\right)+\beta^{\prime}\left(\mathbf{x}_{\text {it }}-\overline{\mathbf{x}}_{. t}\right)+\left(\mu_{i t}-\bar{\mu}_{. t}\right) \\
& \left(\mu_{i t}-\bar{\mu}_{. t}\right)=\left(\phi_{i}-\bar{\phi}\right) f_{t}+\left(\varepsilon_{i t}-\bar{\varepsilon}_{. t}\right) \\
& \text { where, } \bar{y}_{. t}=\frac{1}{N} \sum_{i}^{N} y_{i t} \text { and so on. }
\end{aligned}
$$

In this model error structure is given by $\mu_{i t}=\phi_{i} f_{t}+\varepsilon_{i t}$; where $\mathrm{ft}$ where $f t$ represents the unobserved factor that generates cross-sectional dependence, and $\phi_{i}$ is factor loading. In the above transformation disturbances are expressed in terms of deviations from time-specific averages and therefore, essentially remove the mean impact of $f_{t}$. However, this is effective unless the factor loadings are mean zero, in which case this procedure is not effective at all (Hoyos and Sarafidis, 2006). As we do not have means to verify if the mean factor loading is zero we first estimate PMG with each variable as dependent variable variables in Model 1, which gives us five estimation results. Then we test the residuals of these equations for crosssectional dependence using Pesaran's (2004) cross-sectional dependence (CD) test. The cross-sectional dependence test results reported in Table 7 below indicate that time demeaning of variables have significantly reduced cross-sectional dependency.

Table 7: Cross-sectional dependence for Model I

\begin{tabular}{lccc}
\hline Residual when dependent variable & CD test & $p$ value & Correlation \\
is: & & & \\
LnY & -0.57 & 0.57 & -0.006 \\
LnK & -2.01 & $0.044^{*}$ & -0.023 \\
LnL & 1.13 & 0.259 & 0.011 \\
LnR & 1.13 & 0.26 & 0.013 \\
LnN & -2.59 & $0.010^{* *}$ & -0.029 \\
\hline \multicolumn{2}{c}{ Note: **, and * indicate significant at 5\%, and 10\% level respectively. }
\end{tabular}

The above results indicate that the null hypothesis of cross-scetional independence is not rejected in three cases. For $\mathrm{LnK}$ and $\mathrm{LnN}$ equations null is rejected at $10 \%$ and $5 \%$ levels respectively, which cannot be considered highly significant results. Moreover the correlations 
among the cross-scetional units are also very low. Overall the results suggest that the mean factor loading is not zero and hence time demeaning works well in reducing cross-sectional dependence significantly. Short-run and long-run causality test results with cross-sectional dependence are reported in Table 8.

Table 8: Long-run and short-run causality - Model I

\begin{tabular}{|c|c|c|c|c|c|c|}
\hline \multirow{3}{*}{$\begin{array}{l}\text { Dependent } \\
\text { variables }\end{array}$} & \multicolumn{5}{|c|}{ Sources of causation } & \multirow{2}{*}{$\begin{array}{l}\text { Long-run } \\
\text { causation }\end{array}$} \\
\hline & \multicolumn{5}{|c|}{ Short-run causation } & \\
\hline & $\Delta \operatorname{Ln} Y$ & $\Delta \operatorname{LnK}$ & $\Delta L n L$ & $\Delta \operatorname{LnR}$ & $\Delta L n N$ & $E C$ \\
\hline \multirow{2}{*}{$\Delta L n Y$} & & $0.1248 * * *$ & $0.1860 *$ & $0.0196 * * *$ & $0.0476^{* * *}$ & $-0.1518 * * *$ \\
\hline & & $(0.0185)$ & $(0.0951)$ & $(0.0051)$ & $(0.0162)$ & $(0.0316)$ \\
\hline \multirow[t]{2}{*}{$\Delta \operatorname{LnK}$} & $3.4216 * *$ & & -5.7150 & -0.0250 & -0.4262 & 0.1512 \\
\hline & $(1.3864)$ & & $(6.1065)$ & $(0.0321)$ & $(0.4413)$ & $(0.3867)$ \\
\hline \multirow[t]{2}{*}{$\triangle L n L$} & -0.0139 & -0.0091 & & 0.0054 & 0.0201 & $-0.1390 * * *$ \\
\hline & $(0.0640)$ & $(0.0160)$ & & $(0.0063)$ & $(0.0153)$ & $(0.0392)$ \\
\hline \multirow[t]{2}{*}{$\triangle L n R$} & 0.6985 & 0.2126 & 0.6150 & & - & $-0.1800 * * *$ \\
\hline & $(0.6343)$ & $(0.1393)$ & $(0.7064)$ & & $\begin{array}{l}1.0539 * * * \\
(0.2899)\end{array}$ & $(0.0463)$ \\
\hline \multirow[t]{2}{*}{$\triangle L n N$} & $0.5280 * * *$ & 0.0454 & -0.3179 & $-0.0557 * * *$ & & $-0.3343 * * *$ \\
\hline & $(0.1827)$ & $(0.0426)$ & $(0.2427)$ & $(0.0181)$ & & $(0.0546)$ \\
\hline
\end{tabular}

Figures in parentheses are standard errors. ***, **, and * indicate significant at 1\%, 5\%, and $10 \%$ level respectively.

The results reported in Table 8 show that in LnY equation real gross fixed capital formation (GFCF), total labor force, and renewable and non-renewable energy consumption all have a positive and significant effect on real GDP. The coefficient of gross fixed capital formation and consumption of renewable and non-renewable energy are significant at $1 \%$ level, while coefficient of labor force is significant at $10 \%$.level. This finding suggests that real gross fixed capital formation, total labor force, and renewable and non-renewable energy consumption Granger cause economic growth in the short run. The highly significant (at $1 \%$ level) and correctly signed error correction term of this equation indicates that real GFCF, total labor force, and renewable and non-renewable energy consumption also cause real GDP in the long run. In second equation, in which real gross fixed capital formation is the dependent variable, the impact of real GDP is positive and statistically significant at the 5\% levels. However, no significant impacts of labour force and renewable and non-renewable energy consumption on the real GFCF are found. This result suggests that in the short run causality runs from only real GDP to real GFCF. Insignificant and incorrectly signed error correction term indicate that no long-run causality exists between gross capital formation and the independent variables in this equation. With regard to the third equation, we do not find any evidence of causality from any variable to the labor force in the short run; however, 
negative and significant error correction term indicate that in the long-run causality runs from real GDP, real GFCF, and consumption of renewable and non-renewable energy to labour force. One possible source of this finding may be use of annual data. Most of the short-run changes in unemployment/employment are reflected in monthly or quarterly data. So, use of annual data may not capture those dynamics.

With respect to the fourth equation for renewable energy consumption, the results show that only non-renewable energy consumption has negative and highly significant effect on renewable energy consumption at $1 \%$ level. Negative coefficient implies substitutability between renewable and non-renewable energy. These results indicate that in the short run causality runs from non-renewable energy consumption to renewable energy consumption. Highly significant (at 1\% level) error correction term suggests existence of long-run causality running from independent variables to renewable energy consumption. For non-renewable energy consumption equation, short run causality runs from real GDP and renewable energy consumption variables, both at $1 \%$ significance level. Similar results are found in nonrenewable energy consumption equation; however, in this case coefficient of real GDP is significant at a lower level, i.e. at $1 \%$ level. In this equation long-run causality runs from independent variables to non-renewable energy consumption as indicated by statistically significant error correction term.

In sum, the empirical results indicate that there is bidirectional causality between real GDP and real gross fixed capital formation and between real GDP and non-renewable energy consumption and there is unidirectional causality from labor force and renewable energy to real GDP. No short-run causal link is found between real GFCF and labour force, renewable and non-renewable energy. Also no short-run causality is found between labour force and renewable and non-renewable energy. Causality is also found between real gross capital formation and renewable energy consumption, and between real gross capital formation and non-renewable energy consumption.

The results of bidirectional causality between real GDP and non-renewable energy consumption are consistent with Apergis and Payne (2013), who also investigate the two types of energy simultaneously for 85 developed and developing countries. The results of the relationship between real GDP and non-renewable energy consumption are similar to the findings of Apergis and Payne (2011a) for 16 emerging economies and of Apergis and Payne (2012) for six Central American countries. However, the results with respect to the relationship between economic growth and renewable energy use contradict with that of 
Apergis and Payne (2011a) which find unidirectional causality from GDP to renewable energy use.

The finding of bidirectional causality between economic growth and non-renewable energy confirms the feedback hypothesis, implying that a high level of economic growth leads to high level of consumption of non-renewable energy and vice versa. However, governments should substitute renewable energy sources for non-renewable energy sources and should encourage more usage of renewables to mitigate pollutant emissions.

From the above discussion of causality analysis one policy related issue emerges. In both renewable and non-renewable equations we find negative relation between these two energy consumptions and they are significant at $1 \%$ levels; however, the coefficient values are dramatically different. A $1 \%$ increase in non-renewable energy consumption reduces renewable consumption by almost the same magnitude $(1.05 \%)$, whereas, a $1 \%$ increase in renewable energy consumption reduces consumption of non-renewable energy by a very negligible amount, only $0.056 \%$. This indicates that there is a long way to go to establish non-renewable energy as an established and secured source of energy. This finding suggests that effective government policy is required to promote the use of renewable energy to mitigate the adverse environmental effect of non-renewable energy use.

Table 9: PMG result of short and long run causality: Model II

\begin{tabular}{|c|c|c|c|c|c|c|}
\hline \multirow{3}{*}{$\begin{array}{l}\text { Dependent } \\
\text { variables }\end{array}$} & \multicolumn{5}{|c|}{ Sources of causation } & \multirow{2}{*}{$\begin{array}{l}\text { Long-run } \\
\text { causation }\end{array}$} \\
\hline & \multicolumn{5}{|c|}{ Short-run causation } & \\
\hline & $\Delta L n I V$ & $\Delta \operatorname{LnK}$ & $\Delta L n L$ & $\Delta \operatorname{LnR}$ & $\Delta L n N$ & \\
\hline \multirow{2}{*}{$\triangle L n I V$} & & $0.3637 * * *$ & $0.2717 *$ & $0.0307 * *$ & $0.1397 * * *$ & $-0.1563 * * *$ \\
\hline & & $(0.0354)$ & $(0.1621)$ & $(0.0143)$ & $(0.0447)$ & $(0.0413)$ \\
\hline \multirow[t]{2}{*}{$\Delta L n K$} & $0.9566 * * *$ & & $0.5646^{*}$ & -0.0074 & -0.0774 & $-0.2432 * * *$ \\
\hline & $(0.1588)$ & & $(0.3431)$ & $(0.0306)$ & $(0.0514)$ & $(0.0487)$ \\
\hline \multirow[t]{2}{*}{$\triangle L n L$} & 0.0017 & -0.0072 & & -0.0036 & -0.0019 & $-0.1016^{* * *}$ \\
\hline & $(0.0326)$ & $(0.0184)$ & & $(0.0064)$ & $(0.0154)$ & $(0.0301)$ \\
\hline \multirow[t]{2}{*}{$\triangle L n R$} & $1.1165^{* *}$ & -0.2366 & -0.6133 & & $-0.935 * * *$ & $-0.3984 * * *$ \\
\hline & $(0.4395)$ & $(0.1887)$ & $(0.9536)$ & & $(0.2950)$ & $(0.0726)$ \\
\hline \multirow[t]{2}{*}{$\Delta \operatorname{LnN}$} & $0.2970 * * *$ & 0.0530 & -0.2766 & $-0.0594 * * *$ & & $-0.2795 * * *$ \\
\hline & $(0.0804)$ & $(0.0459)$ & $(0.2754)$ & $(0.0228)$ & & $(0.0443)$ \\
\hline
\end{tabular}

Standard errors are presented in parentheses. $* * *, * *$, and * indicate that the test statistic is significant at the $1 \%, 5 \%$, and $10 \%$ level, respectively. The optimal lag length for the variables is one, determined by the Schwarz Information Criteria. ECT indicates the estimated error correction term.

Next we estimate Model II. Diagnostic tests in Table 1 indicate that Model II does not suffer from cross-sectional dependence problem. We therefore apply PMG estimator without the original variables. The results are reported in Table 9. The results of Granger causality between the variables in the first equation indicate that real GFCF and non-renewable energy 
consumption have positive and statistically significant effects at the $1 \%$ level, and labor force and renewable energy consumption have positive and significant effects on industrial output at $5 \%$ and $10 \%$ levels respectively. The findings suggest that capital, labor force, and both renewable and non-renewable energy consumption Granger cause industrial output in the short run. Considering the causal relationship between industrial output and the other variables in the rest of the equations, the results show that industrial output positively and significantly influences gross capital formation, and both renewable and non-renewable energy consumption. This result suggests that industrial output Granger causes capital, and both renewable and non-renewable energy use in the short run.

Overall, the results of Model II (Table 9) indicate that there is bidirectional short-run causality between industrial output and capital, renewable and non-renewable energy consumption. The two-way relationship between industrial output and both types of energy, which supports a feedback hypothesis, implies that renewable and non-renewable energy consumption mutually influence each other in OECD countries in the short run. Therefore, energy conservation in terms of either renewable or non-renewable energy may lead to a reduction in industrial production. However, any negative shock in the process of industrial output may have a negative impact on energy usage.

Negative and significant bi-directional causality between renewable and nonrenewable energy consumption indicate that increase in the consumption of one type of energy reduces consumption of the other type of energy; however, the associated coefficients suggest that this negative impact of one type of energy on the other is asymmetric. A $1 \%$ increase in the consumption of non-renewable energy reduces consumption of renewable energy by $0.935 \%$; whereas, a $1 \%$ increase in the consumption of renewable energy reduces consumption of non-renewable energy by only $0.059 \%$. Moreover, the coefficient of renewable energy (0.0307) in the industrial value added equation indicates that use of nonrenewable energy in the production of industrial output still remains in a very limited scale.

With respect to the long-run causality relationship between the variables, the error correction terms suggest that there is bidirectional causality between industrial output and renewable and non-renewable energy consumption in the long run; however, the magnitude of disequilibrium correction is quite low (0.1563), indicating that it takes much longer time to get back to equilibrium. In other equations too (except renewable energy equation) the error correction terms indicate that restoring long-run equilibrium take quite long period. Only in case of renewable energy consumption equation the adjustment is quicker; nearly $40 \%$ deviation is corrected each year 


\section{Conclusion}

This article aims to investigate the effects of disaggregated energy consumption (renewable and non-renewable) on industrial output as well as on economic growth based on a neoclassical economic growth model. The simultaneous inclusion of renewable and nonrenewable energy consumption in the model allows us to distinguish the relative influence of each type on industrial output and overall economic growth as well as to analyze the substitutability between the energy sources as well as other factors of production. Accounting for structural breaks and cross-sectional dependence the results of cointegration tests indicate the existence of a long-run equilibrium relationship between the variables in both models. With respect to the long-run estimation for real GDP (Model I), the coefficients of real gross fixed capital formation (capital), total labor force, renewable energy and non-renewable energy consumption are positive and significant at the $1 \%$ level. The estimates of elasticities of real GDP with respect to renewable and non-renewable energy consumption are 0.101 and 0.267 respectively while those of industrial output are 0.074 and 0.295 respectively. These finding indicate that a $1 \%$ rise in renewable and non-renewable energy consumption entail a $0.101 \%$ and $0.267 \%$ increase in real GDP and $0.074 \%$ and $0.295 \%$ increase in industrial output respectively. These findings demonstrate that both types of energy stimulate economic growth in OECD countries, but non-renewable energy remains the main driving force behind industrial output and real GDP growth. Given the positive and significant impact of renewable energy on industrial output and GDP growth producing and increasing use of renewable energy can offer a viable alternative to address climate change issues and ensure sustainable economic growth.

The major causality results show that there is bidirectional causality between real GDP and non-renewable energy consumption in both the short and long run. This finding confirms the feedback hypothesis, which implies that a high level of economic growth leads to a high level of consumption in non-renewable energy and vice versa. However, there is unidirectional causality from GDP to renewable energy consumption. This finding implies that economic growth increase demand for renewable energy and therefore, the governments of these countries should pursue active policies to promote renewable energy for sustainable growth. For industrial output model, bidirectional causality is found between industrial output and renewable and non-renewable energy suggesting that energy conservation in terms of either renewable or non-renewable energy may lead to a reduction in industrial production. However, expansion of renewable energy sources can enhance industrial output in these mature economies and at the same time reduce their pollutant emission. 
The evidence of negative and significant bidirectional causal link between renewable and non-renewable energy consumption is interesting in the sense that reduction of one type of energy entail to increase the other one. This finding indicates the possibility of substitution of renewable energy for non-renewable ones both in industrial output and GDP growth process. Thus, expanding renewable energy sources can be a viable solution for addressing energy security, pollutant emission and climate change issues, and gradually substituting renewable to non-renewable energy sources could enhance a sustainable energy economy. Hence, governments of these economies should continue to their incentivizing policies, such as tax benefits, feed-in tariffs, tax rebates, investment subsidies, and green certificate trading to promote the development of a clean and diversified energy economy. 


\section{Appendix}

Appendix Table 1: Estimated breaks for individual countries

\begin{tabular}{|c|c|c|c|c|c|c|c|}
\hline \multirow[t]{2}{*}{ Countries } & \multirow[t]{2}{*}{ Variables } & \multirow{2}{*}{$\begin{array}{c}\text { Number of } \\
\text { breaks }\end{array}$} & \multicolumn{5}{|c|}{ Dates of breaks } \\
\hline & & & 1 & 2 & 3 & 4 & 5 \\
\hline \multirow{6}{*}{ Australia } & LnL & 2 & 1983 & 1997 & & & \\
\hline & LnGDP & 4 & 1986 & 1989 & 1994 & 2001 & \\
\hline & LnIV & 3 & 1983 & 1996 & 2002 & & \\
\hline & LnK & 2 & 1984 & 1994 & & & \\
\hline & LnR & 2 & 1986 & 1994 & & & \\
\hline & $\mathrm{LnN}$ & 1 & 1981 & & & & \\
\hline \multirow[t]{6}{*}{ Austria } & $\mathrm{LnL}$ & 3 & 1982 & 1989 & 1993 & & \\
\hline & LnGDP & 4 & 1982 & 1992 & 1998 & 2002 & \\
\hline & LnIV & 2 & 1982 & 1992 & & & \\
\hline & LnK & 1 & 1988 & & & & \\
\hline & LnR & 3 & 1981 & 1989 & 1999 & & \\
\hline & $\mathrm{LnN}$ & 2 & 1983 & 1998 & & & \\
\hline \multirow[t]{6}{*}{ Belgium } & LnL & 2 & 1983 & 1989 & & & \\
\hline & LnGDP & 3 & 1988 & 1996 & 2002 & & \\
\hline & LnIV & 2 & 1983 & 2003 & & & \\
\hline & LnK & 2 & 1983 & 1994 & & & \\
\hline & LnR & 1 & 1991 & & & & \\
\hline & $\mathrm{LnN}$ & 2 & 1988 & 1999 & & & \\
\hline \multirow[t]{6}{*}{ Canada } & $\mathrm{LnL}$ & 2 & 1985 & 1997 & & & \\
\hline & LnGDP & 2 & 1983 & 1998 & & & \\
\hline & LnIV & 3 & 1983 & 1995 & 2002 & & \\
\hline & LnK & 2 & 1984 & 1998 & & & \\
\hline & LnR & 3 & 1986 & 1997 & 2001 & & \\
\hline & $\mathrm{LnN}$ & 1 & 1983 & & & & \\
\hline \multirow[t]{6}{*}{ Chile } & LnL & 2 & 1987 & 1996 & & & \\
\hline & LnGDP & 2 & 1988 & 1999 & & & \\
\hline & LnIV & 3 & 1983 & 1996 & 2001 & & \\
\hline & LnK & 2 & 1980 & 1990 & & & \\
\hline & LnR & 2 & 1988 & 1999 & & & \\
\hline & LnN & 2 & 1987 & 1999 & & & \\
\hline \multirow[t]{6}{*}{ Denmark } & LnL & 2 & 1987 & 1995 & & & \\
\hline & LnGDP & 3 & 1982 & 1993 & 2000 & & \\
\hline & LnIV & 2 & 1984 & 1992 & & & \\
\hline & LnK & 1 & 1988 & & & & \\
\hline & LnR & 2 & 1986 & 1998 & & & \\
\hline & $\mathrm{LnN}$ & 1 & 1984 & & & & \\
\hline \multirow[t]{6}{*}{ Finland } & LnL & 1 & 1987 & & & & \\
\hline & LnGDP & 3 & 1985 & 1997 & 2002 & & \\
\hline & LnIV & 2 & 1983 & 1994 & & & \\
\hline & LnK & 2 & 1981 & 1989 & & & \\
\hline & LnR & 2 & 1991 & 2003 & & & \\
\hline & $\mathrm{LnN}$ & 1 & 1990 & & & & \\
\hline France & $\mathrm{LnL}$ & 2 & 1982 & 1998 & & & \\
\hline
\end{tabular}




\begin{tabular}{|c|c|c|c|c|c|c|c|}
\hline \multirow[t]{2}{*}{ Countries } & \multirow[t]{2}{*}{ Variables } & \multirow{2}{*}{$\begin{array}{c}\text { Number of } \\
\text { breaks }\end{array}$} & \multicolumn{5}{|c|}{ Dates of breaks } \\
\hline & & & 1 & 2 & 3 & 4 & 5 \\
\hline & LnGDP & 2 & 1983 & 1999 & & & \\
\hline & LnIV & 2 & 1989 & 2001 & & & \\
\hline & LnK & 2 & 1988 & 2002 & & & \\
\hline & LnR & 3 & 1988 & 1989 & 2001 & & \\
\hline & $\mathrm{LnN}$ & 2 & 1983 & 1998 & & & \\
\hline \multirow[t]{6}{*}{ Germany } & LnL & 1 & 1985 & & & & \\
\hline & LnGDP & 4 & 1984 & 1994 & 1998 & 2002 & \\
\hline & LnIV & 2 & 1985 & 1997 & & & \\
\hline & LnK & 1 & 1983 & & & & \\
\hline & LnR & 2 & 1983 & 1999 & & & \\
\hline & $\mathrm{LnN}$ & 2 & 1984 & 1991 & & & \\
\hline \multirow[t]{6}{*}{ Greece } & LnL & 1 & 1986 & & & & \\
\hline & LnGDP & 3 & 1987 & 1997 & 2002 & & \\
\hline & LnIV & 1 & 1985 & & & & \\
\hline & LnK & 1 & 1988 & & & & \\
\hline & LnR & 2 & 1983 & 1998 & & & \\
\hline & $\mathrm{LnN}$ & 2 & 1982 & 1996 & & & \\
\hline \multirow[t]{6}{*}{ Hungary } & $\mathrm{LnL}$ & 1 & 1986 & & & & \\
\hline & LnGDP & 1 & 1984 & & & & \\
\hline & LnIV & 2 & 1983 & 1994 & & & \\
\hline & LnK & 1 & 1989 & & & & \\
\hline & LnR & 3 & 1982 & 1997 & 2001 & & \\
\hline & $\mathrm{LnN}$ & 2 & 1983 & 1997 & & & \\
\hline \multirow[t]{6}{*}{ Iceland } & $\mathrm{LnL}$ & 1 & 1994 & & & & \\
\hline & LnGDP & 3 & 1985 & 1992 & 1999 & & \\
\hline & LnIV & 2 & 1987 & 1997 & & & \\
\hline & LnK & 1 & 1987 & & & & \\
\hline & LnR & 2 & 1983 & 1992 & & & \\
\hline & $\mathrm{LnN}$ & 1 & 1991 & & & & \\
\hline \multirow[t]{6}{*}{ Ireland } & LnL & 2 & 1985 & 1999 & & & \\
\hline & LnGDP & 4 & 1982 & 1989 & 1994 & 2001 & \\
\hline & LnIV & 2 & 1985 & 1997 & & & \\
\hline & LnK & 1 & 1984 & & & & \\
\hline & LnR & 2 & 1981 & 1987 & & & \\
\hline & $\mathrm{LnN}$ & 2 & 1988 & 1995 & & & \\
\hline \multirow[t]{6}{*}{ Italy } & $\mathrm{LnL}$ & 1 & 1991 & & & & \\
\hline & LnGDP & 4 & 1983 & 1990 & 1998 & 2002 & \\
\hline & LnIV & 2 & 1983 & 1989 & & & \\
\hline & LnK & 1 & 1984 & & & & \\
\hline & LnR & 1 & 1986 & & & & \\
\hline & $\mathrm{LnN}$ & 2 & 1980 & 1997 & & & \\
\hline \multirow[t]{4}{*}{ Japan } & $\mathrm{LnL}$ & 1 & 1981 & & & & \\
\hline & LnGDP & 2 & 1984 & 1998 & & & \\
\hline & LnIV & 3 & 1986 & 1995 & 2002 & & \\
\hline & LnK & 2 & 1988 & 2001 & & & \\
\hline
\end{tabular}




\begin{tabular}{|c|c|c|c|c|c|c|c|}
\hline \multirow[t]{2}{*}{ Countries } & \multirow[t]{2}{*}{ Variables } & \multirow{2}{*}{$\begin{array}{c}\text { Number of } \\
\text { breaks }\end{array}$} & \multicolumn{5}{|c|}{ Dates of breaks } \\
\hline & & & 1 & 2 & 3 & 4 & 5 \\
\hline \multirow{7}{*}{ South Korea } & LnR & 2 & 1983 & 1999 & & & \\
\hline & $\mathrm{LnN}$ & 2 & 1986 & 2000 & & & \\
\hline & LnL & 2 & 1985 & 1991 & & & \\
\hline & LnGDP & 2 & 1988 & 2000 & & & \\
\hline & LnIV & 3 & 1987 & 1997 & 2001 & & \\
\hline & LnK & 2 & 1987 & 1994 & & & \\
\hline & LnR & 1 & 1997 & & & & \\
\hline \multirow{4}{*}{ Luxembourg } & $\mathrm{LnN}$ & 2 & 1980 & 1995 & & & \\
\hline & LnL & 2 & 1986 & 1998 & & & \\
\hline & LnGDP & 3 & 1981 & 1989 & 1998 & & \\
\hline & LnIV & 2 & 1987 & 2001 & & & \\
\hline \multirow{7}{*}{ Mexico } & LnK & 1 & 1984 & & & & \\
\hline & LnR & 2 & 1987 & 1994 & & & \\
\hline & $\mathrm{LnN}$ & 1 & 1982 & & & & \\
\hline & LnL & 2 & 1981 & 1997 & & & \\
\hline & LnGDP & 2 & 1991 & 2002 & & & \\
\hline & LnIV & 2 & 1995 & 2001 & & & \\
\hline & $\mathrm{LnK}$ & 1 & 1984 & & & & \\
\hline \multirow{6}{*}{ Netherlands } & LnR & 2 & 1989 & 1994 & & & \\
\hline & $\mathrm{LnN}$ & 2 & 1989 & 1997 & & & \\
\hline & $\mathrm{LnL}$ & 3 & 1984 & 1988 & 1992 & & \\
\hline & LnGDP & 2 & 1983 & 1997 & & & \\
\hline & LnIV & 2 & 1983 & 1999 & & & \\
\hline & LnK & 2 & 1993 & 2000 & & & \\
\hline \multirow{7}{*}{ New Zealand } & LnR & 1 & 1997 & & & & \\
\hline & $\mathrm{LnN}$ & 1 & 1980 & & & & \\
\hline & $\mathrm{LnL}$ & 2 & 1989 & 1994 & & & \\
\hline & LnGDP & 3 & 1983 & 1997 & 2000 & & \\
\hline & LnIV & 2 & 1986 & 1994 & 2002 & & \\
\hline & LnK & 2 & 1983 & 1991 & & & \\
\hline & LnR & 2 & 1981 & 1986 & & & \\
\hline \multirow{5}{*}{ Norway } & LnN & 1 & 1982 & & & & \\
\hline & LnL & 2 & 1984 & 1991 & & & \\
\hline & LnGDP & 4 & 1984 & 1989 & 1996 & 2004 & \\
\hline & LnIV & 2 & 1983 & 1995 & & & \\
\hline & LnK & 1 & 1997 & & & & \\
\hline \multirow{9}{*}{ Poland } & LnR & 2 & 1984 & 1989 & & & \\
\hline & $\mathrm{LnN}$ & 1 & 1986 & & & & \\
\hline & $\mathrm{LnL}$ & 2 & 1989 & 1996 & & & \\
\hline & LnGDP & 3 & 1982 & 1989 & 1994 & & \\
\hline & LnIV & 4 & 1985 & 1989 & 1992 & 2001 & \\
\hline & LnK & 2 & 1987 & 1995 & & & \\
\hline & LnR & 1 & 1987 & & & & \\
\hline & $\mathrm{LnN}$ & 2 & 1984 & 1998 & & & \\
\hline & LnL & 2 & 1985 & 1999 & & & \\
\hline
\end{tabular}




\begin{tabular}{|c|c|c|c|c|c|c|c|}
\hline \multirow[t]{2}{*}{ Countries } & \multirow[t]{2}{*}{ Variables } & \multirow{2}{*}{$\begin{array}{c}\text { Number of } \\
\text { breaks }\end{array}$} & \multicolumn{5}{|c|}{ Dates of breaks } \\
\hline & & & 1 & 2 & 3 & 4 & 5 \\
\hline & LnGDP & 3 & 1987 & 1991 & 2003 & & \\
\hline & LnIV & 4 & 1986 & 1989 & 1994 & 2001 & \\
\hline & LnK & 1 & 1982 & & & & \\
\hline & LnR & 1 & 1989 & & & & \\
\hline & $\mathrm{LnN}$ & 2 & 1980 & 1996 & & & \\
\hline \multirow[t]{6}{*}{ Spain } & $\mathrm{LnL}$ & 3 & 1987 & 1990 & 1998 & & \\
\hline & LnGDP & 2 & 1989 & 1993 & 2001 & & \\
\hline & LnIV & 2 & 1984 & 1998 & & & \\
\hline & LnK & 3 & 1982 & 1986 & 1997 & & \\
\hline & LnR & 2 & 1988 & 1993 & & & \\
\hline & $\mathrm{LnN}$ & 2 & 1983 & 1989 & & & \\
\hline \multirow[t]{6}{*}{ Sweden } & $\mathrm{LnL}$ & 2 & 1984 & 1996 & & & \\
\hline & LnGDP & 4 & 1982 & 1987 & 1994 & 2003 & \\
\hline & LnIV & 2 & 1983 & 1998 & & & \\
\hline & LnK & 1 & 1983 & & & & \\
\hline & LnR & 1 & 1997 & & & & \\
\hline & $\mathrm{LnN}$ & 1 & 1984 & & & & \\
\hline \multirow[t]{6}{*}{ Switzerland } & $\mathrm{LnL}$ & 3 & 1987 & 1991 & 2002 & & \\
\hline & LnGDP & 2 & 1986 & 1999 & & & \\
\hline & LnIV & 4 & 1987 & 1997 & 2000 & 2004 & \\
\hline & LnK & 2 & 1986 & 1991 & & & \\
\hline & LnR & 2 & 1983 & 1993 & & & \\
\hline & $\mathrm{LnN}$ & 2 & 1986 & 1994 & & & \\
\hline \multirow[t]{6}{*}{ Turkey } & $\mathrm{LnL}$ & 2 & 1989 & 1997 & & & \\
\hline & LnGDP & 3 & 1984 & 1989 & 1994 & & \\
\hline & LnIV & 2 & 1984 & 2000 & & & \\
\hline & LnK & 2 & 1986 & 1989 & & & \\
\hline & LnR & 2 & 1981 & 2000 & & & \\
\hline & $\mathrm{LnN}$ & 2 & 1989 & 1998 & & & \\
\hline \multirow[t]{6}{*}{ UK } & LnL & 2 & 1983 & 1988 & & & \\
\hline & LnGDP & 3 & 1987 & 1993 & 2001 & & \\
\hline & LnIV & 2 & 1980 & 1991 & & & \\
\hline & LnK & 1 & 1986 & & & & \\
\hline & LnR & 1 & 1989 & & & & \\
\hline & $\mathrm{LnN}$ & 2 & 1989 & 1997 & & & \\
\hline \multirow[t]{6}{*}{ US } & $\mathrm{LnL}$ & 2 & 1989 & 1996 & & & \\
\hline & LnGDP & 2 & 1984 & 1997 & & & \\
\hline & LnIV & 2 & 1989 & 2000 & & & \\
\hline & LnK & 2 & 1993 & 1998 & & & \\
\hline & LnR & 2 & 1987 & 1996 & & & \\
\hline & $\mathrm{LnN}$ & 3 & 1982 & 1993 & 2002 & & \\
\hline
\end{tabular}




\section{References}

Apergis, N. and J. E. Payne. 2009. Energy consumption and economic growth: Evidence from the Commonwealth of Independent States, Energy Economics, 31: 641-647.

Apergis, N., Payne, J.E., 2010a. Energy consumption and growth in South America: evidence from a panel error correction model. Energy Economics, 32: 1421 -1426.

Apergis, N., Payne, J.E., 2010b. The emissions, energy consumption, and growth nexus: evidence from the commonwealth of independent states. Energy Policy 38: 650-655.

Apergis, N. and J. E. Payne. 2010c. Renewable energy consumption and growth in Eurasia. Energy Economics 32 (6):1392-1397.

Apergis, N. and J. E. Payne. 2010d. Renewable energy consumption and economic growth: Evidence from a panel of OECD countries. Energy Policy 38: 656-660.

Apergis, N. and J. E. Payne. 2011. The renewable energy consumption-growth nexus in Central America. Applied Energy 88: 343-347.

Apergis, N., Payne, J.E. 2012. Renewable and Non-Renewable Energy Consumption-Growth Nexus: Evidence from a Panel Error Correction Model, Energy Economics, 34: 733738.

Apergis, N., Payne, J.E., Menyah, K., Wolde-Rufael, Y., 2010. On the causal dynamics between emissions, nuclear energy, renewable energy, and economic growth, Ecological Economics, 69: 2255-2260.

Apergis, N., Tang, C. F., 2013. Is the energy-led growth hypothesis valid? New evidence from a sample of 85 countries. Energy Economics 38, 24-31.

Arbex, M. and F. S. Perobelli. 2010. Solow meets Leontief: Economic growth and energy consumption. Energy Economics 32: 43-53.

Bai, J. and P. Perron. 2003. Computation and analysis of multiple structural change model. Journal of Applied Econometrics, 18: 1-9.

Belke, A., Dobnik, F. and Dreger, C. 2011. Energy consumption and economic growth: New insights into the cointegration relationship, Energy Economics, 33: 782-789.

Bowden, N. and Payne, N. 2009. The causal relationship between US energy consumption and real output: A disaggregated analysis. Journal of Policy Modelling 31: 180-188.

Breitung, J. 2000. The local power of some unit root tests for panel data. Advances in Econometrics 15:161-178.

Carrión-i-Silvestre, J. L., T. Del Barrio, and E. López-Bazo. 2005. Breaking the panels. An application to the GDP per capita, Econometrics Journal 8:159-175.

Chien, T., Hu, J.L., 2007. Renewable energy and macroeconomic efficiency of OECD and non-OECD economies. Energy Policy 35: 3606-3615.

Chontanawat, J., Hunt, L.C., Pierse , R., 2008. Does energy consumption cause economic growth? Evidence from a systematic study of over 100 countries. Journal of Policy Modelling 30(2), 209-220.

Eberhardt, M. 2012. Estimating panel time-series models with heterogeneous slopes. The Stata Journal, 12(1): 61 - 71. 
Eberhardt, M., and S. Bond, 2009. Cross-section dependence in nonstationary panel models: A novel estimator. MPRA Paper 17692, University Library of Munich. http://mpra.ub.uni-muenchen.de/17692/1/MPRA_paper_17692.pdf

Eggoh, J. C., Bangaké, C. and Rault, C. 2011. Energy consumption and economic growth revisited in African countries, Energy Policy, 39: 7408-7421

Energy Information Administration (EIA) 2013. International Energy Outlook 2012, U.S. Department of Energy, Washington, DC.

Engle, R. F. and Granger, C. W. J. 1987. Co-integration and error-correction: Representation, estimation and testing. Econometrica 55:251-276.

Fang, Y., 2011. Economic welfare impacts from renewable energy consumption: the China experience. Renewable Sustainable Energy Review, 15: 5120 -5128.

Fayad, Ghada 2010. Remittances and Dutch disease: A dynamic heterogeneous panel analysis on the Middle East and North Africa region. Working paper, Centre for the Study of African Economies, Department of Economics, University of Oxford, UK.

Fuinhas, J. A. and Marques, A. C. (2012) Energy consumption and economic growth nexus in Portugal, Italy, Greece, Spain and Turkey: An ARDL bounds test approach (19652009), Energy Economics, 34: 511-517.

Hardi, K. 2000. Testing for stationarity in heterogeneous panel data. Econometrics Journal 3:148-161.

Hoyos, Rafael E. and Vasilis Sarafidis (2006) Testing for cross-scetional dependence in panel-data models. The Stata Journal 6(4): $482-496$.

Huang, B.N., Hwang, M.J., Yang, C.W., 2008. Causal relationship between energy consumption and GDP growth revisited: a dynamic panel data approach. Ecological Economics 67: 41-54.

International Energy Agency (IEA) 2012. Energy Balances of OECD Countries. International Energy Agency (IEA), Paris.

Im, K., M. H. Pesaran, and Y. Shin. 2003. Testing for unit roots in heterogeneous panels. Journal of Econometrics 115 (1):53-74.

International Energy Agency (IEA) 2013. World Energy outlook 2012. http://www.eia.gov/forecasts/ieo/more highlights.cfm

Kapetanios, G., Pesaran, M.H., 2007. Alternative approaches to estimation and inference in large multifactor panels: small sample results with an application to modelling of asset returns. In: Phillips, G.D.A., Tzavalis, E. (Eds.), The Refinement of Econometric Estimation and Test Procedures: Finite Sample and Asymptotic Analysis. Cambridge University Press, Cambridge.

Kapentanios, George, M.H. Pesaran and Takashi Yamagata 2011. Panels with non-stationary multifactor error structures. Journal of Econometrics, 160(2): 326 - 348.

Kaplan, M., Ozturk, I., Kalyoncu, H., 2011. Energy Consumption and Economic Growth in Turkey: Cointegration and Causality Analysis, Romanian, Journal of Economic Forecasting, 2, p. 31-41.

Kraft, J., and Kraft, A., 1978. On the relationship between energy and GNP. Journal of Energy Development 3,401-403. 
Kwiatkowski, D., P. C. B. Phillips, P. Schmidt, Y. Shin. 1992. Testing the Null Hypothesis of Stationarity against the Alternative of a Unit Root, Journal of Econometrics 54:159178.

Levin, A., C.-F. Lin, and C.S.J. Chu. 2002. Unit root tests in panel data: asymptotic and finite sample properties. Econometrics 108:1-24.

Liao, Q., Z. Wu, and J. Xu. 2010. A new production function with technological innovation factor and its application to the analysis of energy-saving effect in LSD. Modelling and Simulation 6 (4):257-266.

Lise, W. and Montfort, K. V. (2007) Energy consumption and GDP in Turkey: Is there a co-integration relationship? Energy Economics, 29: 1166-1178.

Liu, Haoming and Jinli Zeng 2008. Determinants of long-run unemployment. Southern Economic Journal, 74(3): 775 - 793.

Menegaki, A.N., 2011. Growth and renewable energy in Europe: a random effect model with evidence for neutrality hypothesis. Energy Economics, 33: 257-263.

Narayan, P.K. and Smyth, R. 2008. Energy consumption and real GDP in G7 countries: new evidence from panel cointegration with structural breaks. Energy Economics 30: 2331-2341.

Ozturk, I. 2010. A literature survey on energy-growth nexus, Energy Policy 38:340-349.

Payne, J.E., 2009. On the dynamics of energy consumption and output in the US. Applied Energy, 86: 575-577.

Payne, J.E., 2011. On biomass energy consumption and real output in the US, Energy Sources Part B 6 (1), 47-52.

Pedroni, P. 2004. Panel cointegration: asymptotic and finite sample properties of pooled time series tests with an application to the PPP hypothesis: new results. Econometric Theory, 20: 597-627.

Perron, P. 1989. The great crash, the oil price shock and the unit root hypothesis. Econometrica 57:1361-1401.

Persyn, D. and J. Westerlund, 2008. Error-correction based cointegration tests for panel data. Stata Journal. 8: 232-241.

Pesaran, M. H. 2004. General Diagnostic Tests for Cross Section Dependence in Panels. Cambridge Working Paper in Economics 0435.

Pesaran, M.H. 2006. Estimation and inference in large heterogeneous panels with a multifactor error structure. Econometrica 74: 967 - 1012.

Pesaran, M.H. and Elisa Tosetti 2011. Large panels with common factors and spatial correlations. Econometrics 161(2):182-202

Pesaran, M.H. and R. Smith 1995. Estimating long-run relationship from dynamic heterogeneous panels. Journal of Econometrics, 68(1): 79 - 113.

Pesaran, M.H., and R. P. Smith 1995. Estimating long-run relationship from dynamic heterogeneous panels. Journal of Econometrics, 68: 79 - 113.

Pesaran, M.H., R. Smith and Y Shin, 1999. Pooled mean group estimation of dynamic heterogeneous panels. Journal of the American Statistical Association 94(446): 621 634. 
Phillips, P. C. B., and D. Sul. 2007. Bias in dynamic panel estimation with fixed effects, incidental trends and cross section dependence. Journal of Econometrics 137 (1):162188.

Santana-Gallego, María, Francisco Ledesma-Rodríguez and Jorge V. Pérez- Rodríguez 2011. Tourism and trade in OECD countries. A dynamic heterogeneous panel data analysis. Sadorsky, P. 2009b. Renewable Energy Consumption, CO2 Emissions and Oil Prices in the G7 Countries. Energy Economics 31: 456-62.

Sadorsky, P., 2009a. Renewable energy consumption and income in emerging economies. Energy Policy 37: 4021-4028.

Sadorsky, P. 2009b. Renewable Energy Consumption, CO2 Emissions and Oil Prices in the G7 Countries. Energy Economics 31: 456-62.

Sari, R., Soytas, U. (2004). Disaggregate energy consumption, employment and income in Turkey, Energy Economics 26: 335-344.

Soytas, U., \& Sari, R. (2006), Energy consumption and income in G-7 countries, Journal of Policy Modelling 28 (7), 739-750.

Soytas, U., Sari, R. and Ewing, B.T. 2007. Energy consumption, income, and carbon emissions in the United States, Ecological Economics 62: 482-489.

Stock, J. H. and M. W. Watson. 1993. A simple estimator of cointegrating vectors in higher order integrated systems. Econometrica, 61: 783-820.

Sul, D., Phillips, P.C.B., Choi, C.Y., 2005. Prewhitening bias in HAC estimation. Oxford Bulletin Economics Statistics. 67, 517-546.

Tugcu, C. T, I. Ozturk and A. Aslan. 2012. Renewable and non-renewable energy consumption and economic growth relationship revisited: Evidence from G7 countries. Energy Economics 34:1942-1950.

Westerlund, J. 2006. Testing for panel cointegration with multiple structural breaks. Oxford Bulletin of Economics and Statistics, 68:101-132.

Westerlund, J. 2007. Testing for error correction in panel data. Oxford Bulletin of Economics and Statistics, 69:709-748.

Wooldridge, J. M. 2002. Econometric Analysis of Cross Section and Panel Data: Cambridge, MA: MIT Press.

World Bank. 2013. World Development Indicators 2013, Washington, DC: World Bank.

Yildirim, E. and Aslan, A. 2012. Energy consumption and economic growth nexus for 17 highly developed OECD countries: Further evidence based on bootstrap-corrected causality tests, Energy Policy, 51: 985-993. 